\title{
Simplicity or complexity? Important aspects of high nature value grassland management in nature conservation
}

\author{
Róbert Kun $^{1}$ (D) Dániel Babai ${ }^{2} \cdot$ András István Csathó $^{3} \cdot$ Csaba Vadász $^{4}$. \\ Nikoletta Kálmán ${ }^{5} \cdot$ András Máté $^{6}$ Ákos Malatinszky ${ }^{1}$
}

Received: 6 September 2020 / Revised: 6 July 2021 / Accepted: 20 July 2021 /

Published online: 31 July 2021

(c) The Author(s) 2021

\begin{abstract}
Local, adaptive traditional grassland management systems have played a fundamental role in the creation, maintenance and conservation of high nature value (HNV) grasslands. The state of diverse HNV grasslands has deteriorated across Europe in conjunction with changes in various management factors, such as management type and management intensity. To conserve the species-rich vegetation of HNV grasslands and to avoid undesirable shifts in plant functional type dominance, it is important to explore the effects of management factors crucial for nature conservation and to adapt them to local circumstances. In our study, we focus on three of the main factors in the management of valuable meadow steppes in the Great Hungarian Plain region (Central Hungary). We studied management types (mowing, grazing and combined), different levels of herbage removal intensity (low, medium, high) and spatio-temporal complexity (low, medium and high) of grassland management. Altogether 172 plots $(1 \mathrm{~m} \times 1 \mathrm{~m})$ were designated in 17 sites. Plant diversity indexes and plant functional types were calculated according to the presence and percentage cover of plant species in the plots. Regarding plant diversity and the dominance of plant functional types, herbage removal intensity and spatio-temporal complexity of management had, for the most part, stronger effects than the type of management. Higher spatio-temporal complexity of management resulted in higher plant diversity, while higher intensity of management led to significantly lower diversity. Proper application of type, intensity and spatio-temporal complexity of management practices (separately and in combination) proved to be determining factors in the long-term maintenance and conservation of diversity and species composition of HNV grasslands.
\end{abstract}

Keywords Complex management systems - Different management factors · Nature conservation value $\cdot$ High nature value $(\mathrm{HNV})$ grasslands

Communicated by Dirk Sven Schmeller.

Róbert Kun

rbert.kun@gmail.com

Extended author information available on the last page of the article 


\section{Introduction}

High nature value (HNV) natural and semi-natural grasslands are organic and important elements of European natural and cultural landscapes which have usually been maintained by extensive (traditional) management systems (Plieninger et al. 2006; Söderström et al. 2001). Grassland ecosystems host $18.1 \%$ of the more than 6000 European endemic vascular plant taxa (Hobohm and Bruchmann 2009). This is nearly twice as many as in forests, despite the latter covering much more land area (Habel et al. 2013). Dry and steppe grasslands in areas with relatively low altitudes in the continental climatic zone in Central and Eastern European countries can host extremely high species diversity with high conservation value as well (e.g., 79 species per square meter in Romania as the record for East-Central Europe-Dengler et al. 2014; Wilson et al. 2012). In Hungary, among others, meadowsteppes are extremely species-rich habitats (38 plant species in $1 \mathrm{~m}^{2}$ and 46 species in $4 \mathrm{~m}^{2}$ were the maximum in extensively managed grasslands (Kun et al. unpubl. 2021)).

Extensive (traditional) farming practices, adapted to local ecological circumstances, played a crucial role in the formation and maintenance of HNV grasslands all over Europe over the past centuries (Babai and Molnár 2014; Dahlström et al. 2013; Fischer and Wipf 2002; Kun et al. 2007; Plieninger et al. 2006). Not only extensive management practices but also the micro (parcel)-scale land-use diversity of these systems has a positive effect on plant species diversity and on the proportion of different plant functional types (PFTse.g., forbs, Poaceae or Fabaceae species) (Kun et al. 2019). Populations of numerous specialist plant species (e.g., Blackstonia acuminata, Iris spuria), as well as animals (e.g., red-listed butterflies such as Maculinea spp.) have adapted to these extensive management practices and patterns on HNV grasslands (Habel et al. 2013; Öckinger et al. 2006; Schmitz and Isselstein 2020). Determining factors are the spatially and temporally diverse combinations of several management elements with various levels of management intensity (e.g., hayseed sowing, manual control of undesirable species, livestock grazing, etc.) (Babai et al. 2014; Kun et al. 2019).

Nevertheless, extensive, traditional grassland management systems have undergone drastic changes all over Europe since the second half of the twentieth century (MacDonald et al. 2000; Plieninger et al. 2006). Shifting from the extensive (traditional) land-use systems towards less complex and more intensive agricultural practices or towards abandonment has led to severe changes (degradation) in the composition of cultural landscapes with HNV grasslands (e.g., increasing fragmentation, disappearing grasslands, decreasing biodiversity) (Bakker and Berendse 1999; Galvánek and Lepš 2008; Házi et al. 2011; Öckinger et al. 2006; Öckinger and Smith 2006; Poschlod et al. 2005; Ruprecht et al. 2010). Accordingly, the disappearance of once widespread extensive land-use systems has resulted in a decline of the area of the grasslands, of the species diversity, drastic changes in species composition and a homogenisation of the vegetation of HNV grasslands across Europe, even despite nature conservation efforts and financial initiatives (see e.g. CAP subsidies) (Austrheim and Eriksson 2001; Csergő et al. 2013; Burton and Paragahawewa 2011; MacDonald et al. 2000; Ruprecht et al. 2010; Spiegelberger et al. 2010). Additional indicators of degradation are changes in functional diversity and dominance among different PFTs (e.g., increasing abundance of generalist, disturbance-tolerant or even invasive alien species) (de Bello et al. 2006). PFTs as indicators create a bridge between plants' physiological characteristics and phytosociological behaviour (Diaz and Cabido 1997), and their relative dominance may differ depending on the type and intensity of grassland management (Austrheim and Eriksson 2001; Duru et al. 2005; Házi et al. 2011; Imrichova and 
Vrahnakis 2005), affecting the quality of harvestable fodder (e.g., hay) (Babai et al. 2015; Duru et al. 2005).

Previous studies have primarily focused on the effects of a single factor (e.g., type or intensity of management) of HNV grasslands' management on biodiversity or on the compositional or dominance relations of the vegetation (de Bello et al. 2006; Fischer and Wipf 2002; Házi et al. 2011; Tälle et al. 2016). Vadász et al. (2016) suggested for consideration the spatio-temporal complexity of management (i.e., how the sequence of application of particular management units varies within a year and from year to year), which is a potential factor maintaining plant diversity of HNV grasslands as well.

It follows from all this that studies on grassland management need to focus on three key management factors simultaneously, namely (1) type of management (mowing, grazing and their combination); (2) herbage removal intensity (expressed in Standard Livestock Unit, see Table 1 and Allen et al. 2011); and (3) spatio-temporal complexity of management (different timing and applied rates of herbage removal intensity levels and management types-for more details see Table 1). Modelling the specific and combined effects of various grassland management factors on plant diversity enables us to identify the key factors (and their linear combinations) which are most relevant for successful nature conservation management.

We aimed to explore the following questions:

- Which management factors and combinations of them have a significant effect on plant diversity?

- Do these management factors separately and in combination significantly affect dominance relations (species number and total cover) among PFT groups?

- What priority do management factors have in how they affect diversity indices, PFT group covers and PFT species numbers, and how do they apply to conservation?

Table 1 List and short introduction of explanatory variables, the analysed management factors

\begin{tabular}{ll}
\hline Management factors & Meanings and scales of management factors \\
\hline Type of grassland management $(T)$ & Mowing $(M)$ \\
& Grazing $(G)$ \\
& Combined (mowing and grazing combined within a year \\
& or between years, $C$ ) \\
& Low: 0.5 standard livestock unit (SLU) per hectare graz- \\
ing, or mowed once a year & Medium: $0.5-0.8$ SLU/ha grazing, or mowed once a year \\
Herbage removal intensity $(I)$ & with subsequent grazing in the same year \\
& High: $>0.8$ SLU/ha grazing livestock \\
& Low: permanent grazing in a single grazing unit (no vari- \\
ance in grazing pressure within and between years) & Medium: grazing with standard within-year sequence of \\
Spatio-temporal complexity of management $(C)$ grazing units, or one mowing with $10 \%$ left uncut, & or mowing once a year combined with subsequent \\
grazing & High: mowing and grazing combined between years, or \\
grazing with a varying sequence of four grazing units & between years \\
\hline
\end{tabular}

Herbage removal intensity of management was expressed by Standard Livestock Unit (SLU), which is a non-lactating bovine weighing $500 \mathrm{~kg}$ (=1 SLU, see Allen et al. 2011) and by mowing frequency per year 


\section{Materials and methods}

\section{Study area}

The study area is located in the Turján region of the Great Hungarian Plain (Central Hungary) (coordinates: $47.04023^{\circ} \mathrm{N} ; 19.15289^{\circ} \mathrm{E}$ ). This region belongs to the continental forest-steppe zone, with a slight sub-Mediterranean climatic effect. Annual mean temperature is $10.4{ }^{\circ} \mathrm{C}$ (Tölgyesi et al. 2016), while annual average rainfall is $520 \mathrm{~mm}$. At the regional level (Turján region), sandy and loamy soils are dominant (Karátson 2002), while in the study area the sandy soils are dominant (Vadász et al. 2016). Potential vegetation of the study area is the Pannonian sandy forest steppe community, but two thirds of the area is covered by the rich mosaic of primary and secondary, semi-natural grasslands grazed by cattle (Hungarian Grey Cattle and Charolais breeds). Our aim was to study spatially scattered primary, ancient grassland sites (or, on the rare occasion, oldfields, abandoned very long ago). This sandy, xero-mesic meadow-steppe habitat is one the dominant grassland types in the study area, being a transitional, species-rich ecotone between Molinia fen meadows (Molinion caeruleae, Natura 2000 code: 6410) and Pannonic sand steppes (Galio veri-Holoschoenetum vulgaris, Natura 2000 code: 6260). Although extensively managed xero-mesic meadow steppes are one of the most species-rich habitat types in Hungary, management-vegetation interactions in this habitat type are understudied from the perspective of nature conservation (Vadász et al. 2016). Adventive and invasive species are rare in the managed grasslands. Dominant, frequent and characterisitic species of this habitat are Chrysopogon gryllus (Poaceae), Molinia caerulea (Poaceae), Serratula tinctoria (Asteraceae), Sanguisorba officinalis (Rosaceae) and Betonica officinalis (Lamiaceae), while many protected species, such as Ophrys scolopax (Orchidaceae) and Iris spuria (Iridaceae), are also present.

\section{Sampling protocol}

This study considers three management factors: (1) type of management $(\boldsymbol{T}),(2)$ intensity of management (I), and (3) spatio-temporal complexity of management $(\boldsymbol{C})$. Management types considered are mowing, grazing and the combination of them; furthermore, three categories of herbage removal intensity (low, medium and high intensity) and three spatiotemporal complexity categories (low, medium and high complexity) were investigated. The sample arrangement, in addition to the mentioned categories, was determined by following the method of Vadász et al. (2016) (Table 1). We aimed to sample consantly managed meadow steppe habitats in the study area. Every sampled grassland site exceeded at least 5 ha in size, in order to exclude sources of variance that emerge from diversity of management and neighbouring or edge effects. Investigations were undertaken in the summer of 2015, on 17 grassland sites, which were ordered by the three management factors $(\boldsymbol{T}, \boldsymbol{I}$, C) (for more details, see Table 1, Appendix Table 12). 10 plots were designated on 15 grassland sites and 11 were designated on two sites, because of the greater extent of the meadow-steppe patches to ensure the proper sampling and interpretation required. Thus, in the end, data gathered in $\mathrm{N}=172$ plots $(1 \mathrm{~m} \times 1 \mathrm{~m}$ each) were evaluated (for more details, see Appendix Fig. 3). Because of the indistinct shape and variable extent of the sampling sites, it was not possible to use a previously determined random protocol in the arrangement of the plots. Therefore we applied linear sampling, where we placed each plot per 
site along transects fitted to special forms of every sites. The location of the first plot of the transect in a given site was determined randomly, while further plots were designated at a minimum of four meters along the transects (for more details, see Appendix Fig. 3). Recorded data at every plot included the name and visually estimated percentage cover of each vascular plant species, and the coordinates of the plots were registered using GPS.

\section{Applied terms and data analysis}

In this paper, we refer to management as all human activities attempting to serve nature conservation or economic purposes in grasslands. Herbage removal intensity and spatiotemporal complexity levels were determined by local farmers and by the local national park ranger with expertise in this area (Csaba Vadász and András Máté-authors of the paper, Kiskunság National Park) (see also Vadász et al. 2016). All the studied management factors (type of management $(\boldsymbol{T})$, herbage removal intensity $(\boldsymbol{I})$ and spatio-temporal complexity $(\boldsymbol{C})$ of management), as explanatory variables, have different technical parameters (e.g., timing, frequency and level of intensity) (Table 1), which are referred to as 'management details' and 'levels' below in the text.

We categorized all observed plant species into eight predefined PFTs, based on habitat requirement, life-history traits, and growth form (Table 2, Borhidi 1995). We used species number and total cover of each PFT, as well as total species number, Shannon diversity and Simpson diversity, as response variables (Table 2, Borhidi 1995). In our analyses, we used percentage cover of all PFTs as like species numbers of them. In case of life history trait classifications, we also used the list of protected species in Hungary (see http\#1). In the life history trait category selection we used only those PFTs, which had hypothetically strongest explanatory and indication power of naturalness and conservation value of the sampled meadow steppe communities (see Borhidi 1996; Hargitai 1940).

Linear mixed models, namely LMER and GLMER were used to evaluate the explanatory power and informativity of the three, studied management factors and their combination on response variables. First, to investigate main effects of management factors (type, intensity, and spatio-temporal complexity) vegetation, we ran three separate models for each response variable: as a function of management type (1: $\boldsymbol{T})$, as a function of herbage removal intensity $(2: \boldsymbol{I})$, and as a function of spatio-temporal complexity (3: $\boldsymbol{C})$. Site was included as a random factor to account for non-independence of plots. Second, to investigate combined effect of management factors, we ran four additional models for each response variable: $4: \boldsymbol{T}+\boldsymbol{I} ; 5: \boldsymbol{T}+\boldsymbol{C} ; 6: \boldsymbol{I}+\boldsymbol{C}$; and $7: \boldsymbol{T}+\boldsymbol{I}+\boldsymbol{C}$. Normality of residuals were checked with the Shapiro-Wilk normality test. In case of non-normally distributed residuals, GLMER models were applied with Gamma family. In some cases, where convergence problem occurred, "log" link was applied in models. After simple model evaluations $(\boldsymbol{T}, \boldsymbol{I}$ and $\boldsymbol{C}$ ), Tukey post hoc tests were applied with "glht" function to evaluate significant differences between levels of different management factors. Bonferroni adjustment method was applied in the post hoc tests to counteract the problem of multiple comparisons. In the models, AICc (corrected Akaike information criterion) values were used to determine model parsimony. Application of AICc values was important and adequate for estimating the relatively few real combinations of the explanatory variables (Burnham and Anderson 2002). Candidate models with strong explanatory power $(\Delta \mathrm{AICc} \leq 4)$ were used for model averaging and model selection. Unadjusted beta $\mathrm{R}^{2}$ values (with ' $\mathrm{r} 2$ beta' function) of models were used to evaluate the amount of explained variance and fit, following the recommendations of Posada and Buckley (2004). Analyses were run with R 3.5.1 (R Core Team 


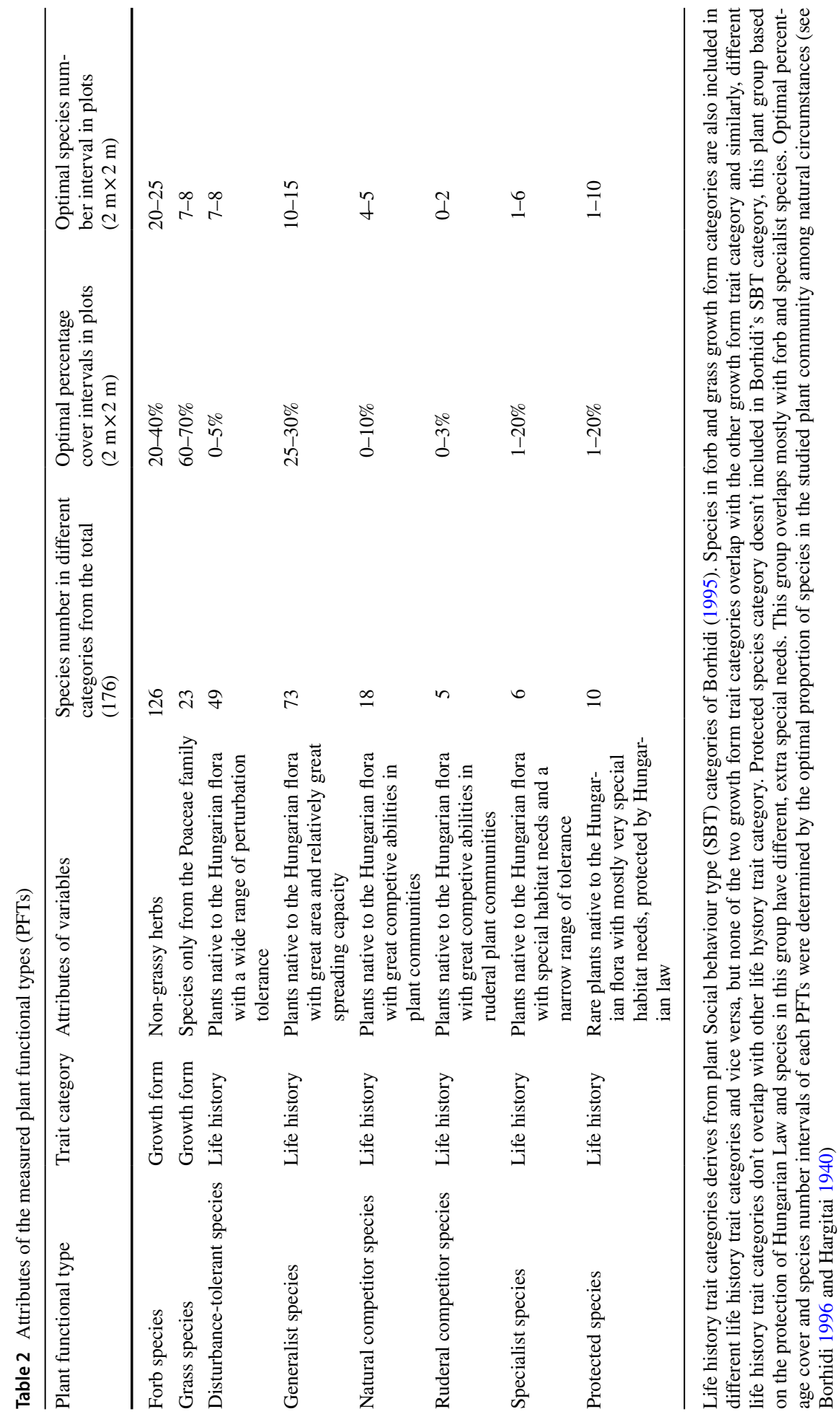


2018) software environment and by 'MuMIn', 'Ime4', 'goft', 'r2glmm', 'multcomp'and the 'vegan' packages.

\section{Results}

During the field work, 4780 records of 176 plant species were collected in a total of 172 plots.

\section{Management factors with strong explanatory power on the dependent variables}

Management type $(\boldsymbol{T})$ as fixed factor, didn't affected strongly plant diversity and most of the PFT covers and numbers. Only generalist species number and disturbance tolerant species cover had relatively strong relationship with $\boldsymbol{T}$ (Tables 4, 5), but significant differences between different management types wasn't experienced (Appendix Table 6). Herbage removal intensity $(\boldsymbol{I})$ had much more stronger effects on diversity, mainly on Shannon diversity and species number and had significant effect on grass, generalist and forbs species coverages (Tables 3,4). Parallelly, spatio-temporal complexity of management $(\boldsymbol{C})$ had the strongest relationships with diversity indices and species number. $\boldsymbol{C}$ had powerful impact on generalist species cover and number as like forb, specialist and disturbance tolerant species numbers (Tables 4, 5). In several cases, simple, univariate models were most parsimonious and had best fits. In case of Shannon and Simpson diversity, simple $\boldsymbol{C}$ model was the most parsimonious. Forb, generalist and disturbance tolerant species coverage had most parsimonious models in relation with single management factors. Similarly, simple models were most parsimonious in case of grass, disturbance tolerant, natural competitor, ruderal competitor, specialist and protected species numbers. On the other hand, in case of species number, grass, natural and ruderal competitor and protected species cover, complex models were more parsimonious (Tables 3, 4, 5). Regarding the aforementioned dependent

Table 3 Simple and complex effects of different management factors on plant diversity

\begin{tabular}{|c|c|c|c|c|c|c|c|c|}
\hline & $\begin{array}{l}\text { Estima- } \\
\text { tors }\end{array}$ & $T$ & $I$ & C & $T+I$ & $T+C$ & $I+C$ & $T+I+C$ \\
\hline \multirow{2}{*}{$\begin{array}{c}\text { Species } \\
\text { num- } \\
\text { ber }\end{array}$} & $\mathrm{AICc}$ & 968.047 & 951.616 & 950.913 & 942.692 & 949.420 & 942.945 & 938.220* \\
\hline & $\mathrm{R}^{2}$ & 0.125 & 0.488 & 0.492 & 0.547 & 0.498 & 0.541 & 0.554 \\
\hline \multirow{2}{*}{$\begin{array}{c}\text { Shannon } \\
\text { diver- } \\
\text { sity }\end{array}$} & $\mathrm{AICc}$ & 73.029 & 71.761 & $66.891 *$ & 72.150 & 70.899 & 71.208 & 74.672 \\
\hline & $\mathrm{R}^{2}$ & 0.160 & 0.225 & 0.380 & 0.352 & 0.383 & 0.377 & 0.392 \\
\hline \multirow{2}{*}{$\begin{array}{l}\text { Simpson } \\
\text { diver- } \\
\text { sity }\end{array}$} & $\mathrm{AICc}$ & - 383.977 & -383.636 & $-387.509 *$ & -382.706 & -383.648 & -383.277 & -380.258 \\
\hline & $\mathrm{R}^{2}$ & 0.147 & 0.128 & 0.272 & 0.255 & 0.280 & 0.271 & 0.301 \\
\hline
\end{tabular}

Effects of explanatory variables - type of grassland management $(\boldsymbol{T})$, herbage removal intensity $(\boldsymbol{I})$ and spatio-temporal complexity of management $(\boldsymbol{C})$ - were measured by using beta $\mathrm{R}^{2}$ values and parsimony by AICc in LMER and GLMER models

*The best model (lowest AICc)

AICc values of candidate models with significant explanatory power (with $\Delta \mathrm{AICc} \leq 4$ ) are written in bold 


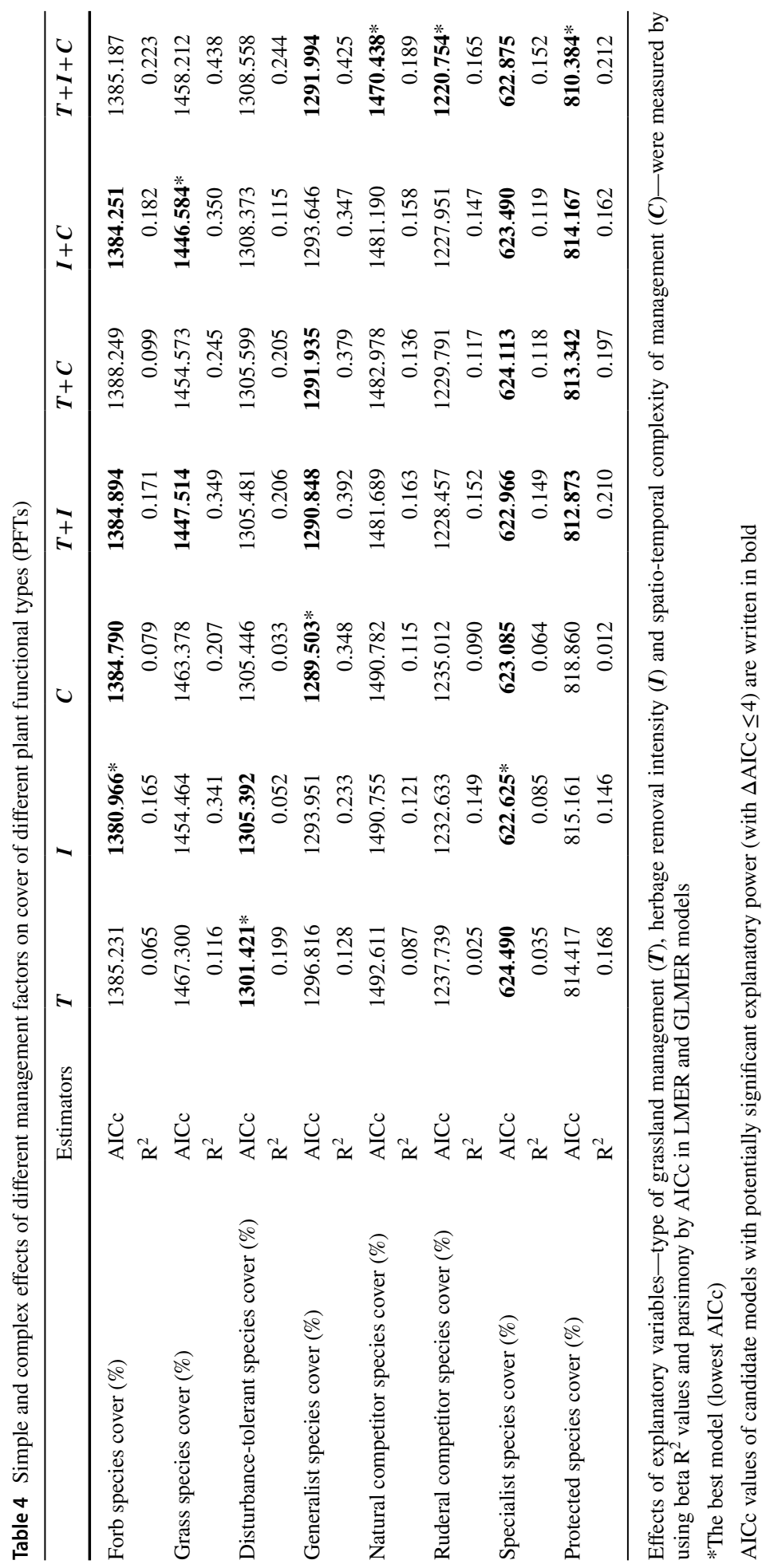




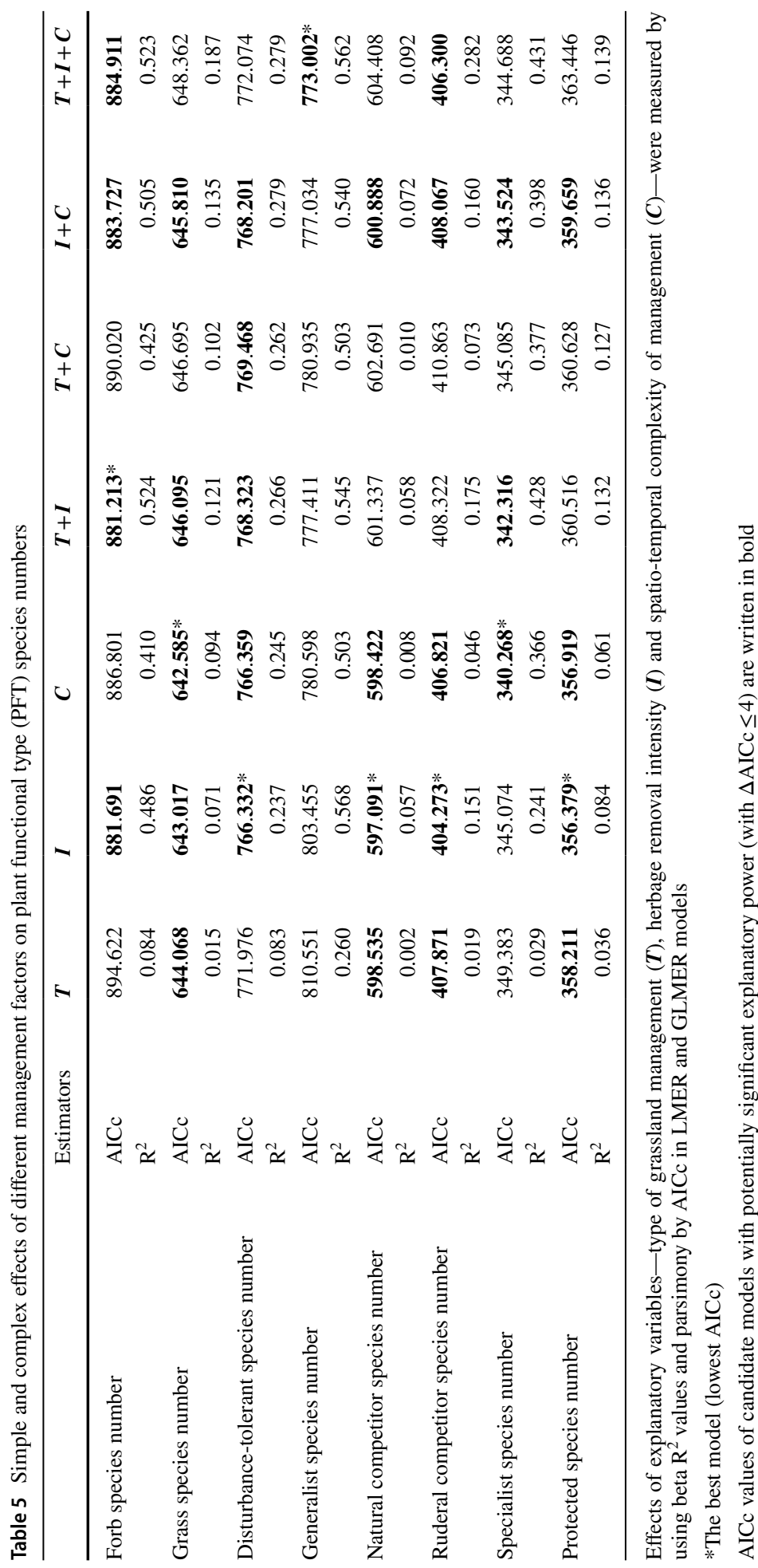


variables, $\mathrm{R}^{2}$ values of complex models with the best fit increased by $\Delta \mathrm{R}^{2}=0.006-0.131$ when compared to the best fitting single-variable models (Tables 3, 4).

For five of the 19 dependent variables, the most complex model $(\boldsymbol{T}+\boldsymbol{I}+\boldsymbol{C})$ was the best: species number, and the cover of natural competitors, ruderal competitors, and protected species as like generalist species number (Tables 3, 4, 5). For the dependent variables forb species number and grass species cover, explanatory power increased by applying a combination of $\boldsymbol{T}, \boldsymbol{I}$ and/or $\boldsymbol{C}$ (Tables 4, 5).

\section{The effect of management types, herbage removal intensity and spatio-temporal complexity levels on plant diversity as well as on coverages and numbers of different plant functional types}

In our study, none of the studied response variables differed significantly by effect of mowing, grazing or combined management based on LMER and GLMER post hoc tests. On the other hand, different levels of $\boldsymbol{I}$ had a strongly negative differential effect on the total number of species, as like on forb species cover. Parallelly, factor $\boldsymbol{I}$ had negative effect on forb, generalist disturbance tolerant species numbers. In contrast, high level of $\boldsymbol{I}$ had strong, positive effect on grass and ruderal competitor species coverages (Appendix Tables 7, 10).

High or medium level of $\boldsymbol{C}$ had strong, positive effect on grassland diversity (Fig. 1, Appendix Tables 8,11) and on the generalist PFT group coverage (Appendix Table 8). Parallelly, higher levels of factor $\boldsymbol{C}$ had strong, positive effects on forb, disturbance tolerant, generalist and specialist species numbers. In contrast, $\boldsymbol{C}$ had strong, negative effect on grass species cover (Fig. 1, Appendix Table 11).

Increasing or decreasing level of $\boldsymbol{I}$ and $\boldsymbol{C}$ were the two, most powerfully forming management factors with mostly opposite effects on plant diversity and PFTs. This phenomenon in details is pictured in Fig. 2 below.

\section{Discussion}

\section{Effect of different management factors and their importance in conservation}

Among the considered management factors, the low and/or medium herbage removal intensity, in line with high spatio-temporal complexity of management resulted in a significantly higher plant species number on the studied grasslands (Appendix Tables 7, 8).

Different management intensity levels affect plant diversity patterns and PFTs' relations (de Bello et al. 2006; Diaz and Cabido 1997; Imrichova and Vrahnakis 2005). Low or medium herbage removal intensity gives room for (1) greater plant heterogeneity (e.g., different reproduction phases or variable height on a management-unit scale) (Austrheim and Eriksson 2001), and (2) increased diversity of plant species. In contrast, high herbage removal intensity can lead to functional and compositional homogenisation, and reduces diversity of grasslands especially in drier grasslands with relatively lower productivity (as our study area as well) (Fedrigo et al. 2018). In our study, high herbage removal intensity alone negatively affected the species number and cover of forbs, while positively affected grass species' cover (Fig. 1, Tables 3, 4 and Appendix Table 7). For example, clonal grasses with great competitive power (e.g. Calamagrostis epigeios and Botriochloa ischaemum) are favoured by high herbage removal intensity (see Öckinger et al. 2006; Malatinszky 2016; Ruprecht et al. 2010), 
(a)

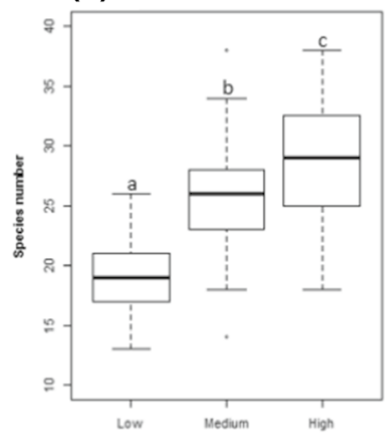

Spatio-temporal complexity of management

(d)

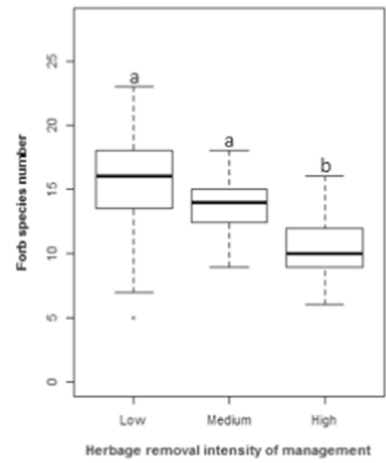

(g)

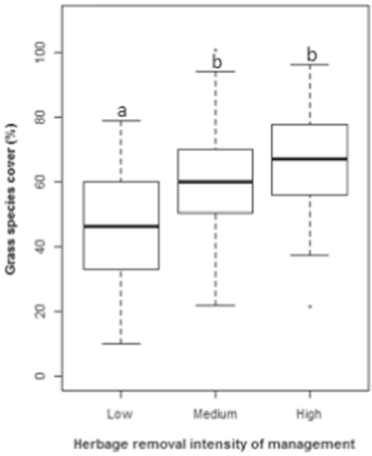

(c)

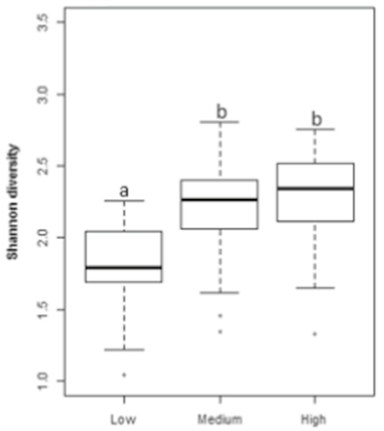

(e)

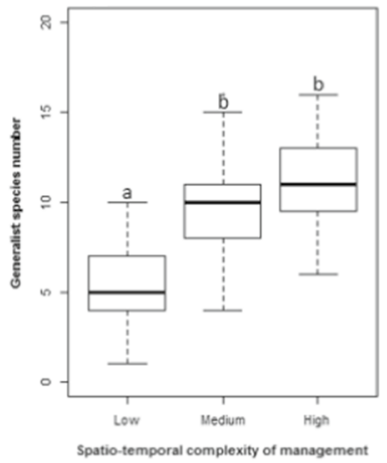

(h)

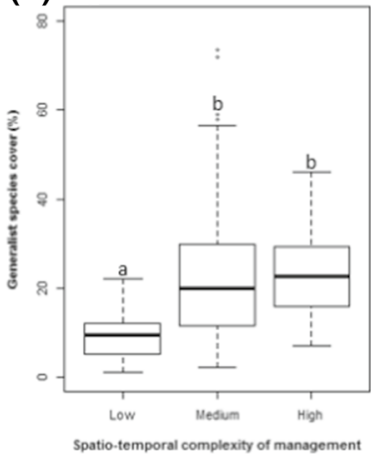

Fig. 1 Significant differences among different levels of particular management factors on dependent variables. Probability level of LMER and GLMER Tukey post hoc tests was $p<0.05$. Significant differences between management factor levels are signed with different letters (' $a$ ', ' $b$ ' and 'c') above each boxplots. If there is not any difference, letters aren't different from each other. Letters from a.)-h.) mean subsections of Fig. 1. Most parsimonious, simplex (univariate) models were selected for this analysis, where the fit of models were relatively high, $R^{2} \geq 0.250$

are able to completely dominate grassland stands (Szentes et al. 2012) and parallelly, reducing the species diversity and leading to a degraded state of grassland composition (Házi et al. 2011; Szentes et al. 2012). Lower level of herbage removal intensity has a 


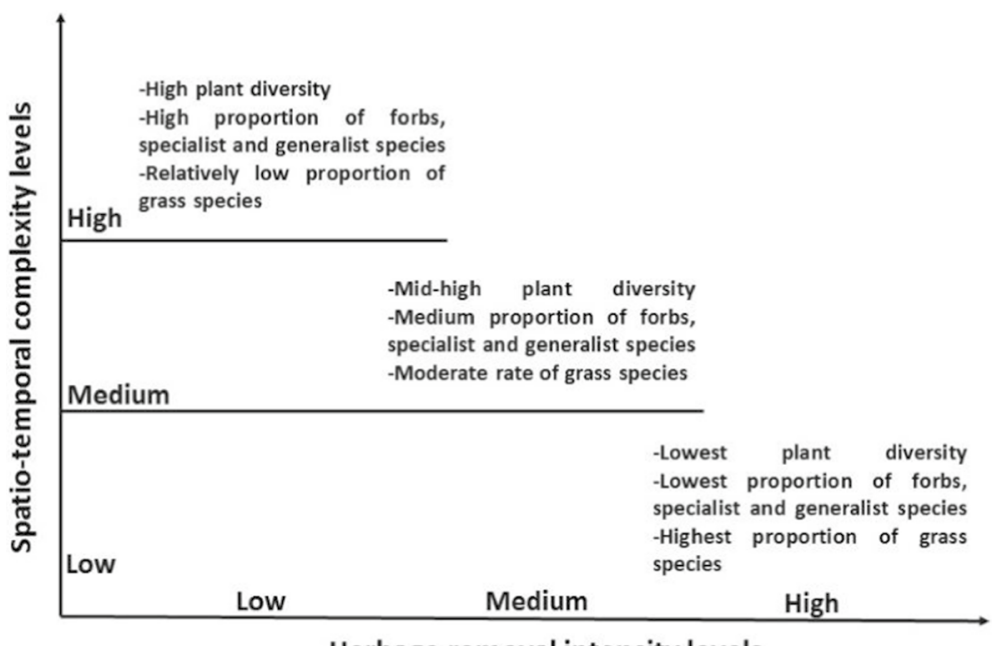

Herbage removal intensity levels

Fig. 2 Overall effects of herbage removal intensity and spatio-temporal complexity of management on plant diversity and plant functional types

positive effect on the proportion between grass and forb species coverage supporting the preservation of the optimal plant composition and diversity (Appendix Tables 7, 10, Fig. 1).

Spatio-temporal complexity of management, namely the application of diverse combinations of mowing and grazing with changing herbage removal intensities between years and within a year can influence the physiognomy, phenology and generative relationships of the grassland vegetation (Kelemen et al. 2017; Szépligeti et al. 2018), and positively affect the diversity and PFTs' dominance relations to a considerable extent (e.g. forb, generalist and specialist species numbers, see Table 5 and Appendix Table 11). This variance in management affects the inter-specific competition by creating temporal reproductive niches (niche partitioning and segregation) (Catorci et al. 2014; Marini et al. 2007). A few years with more intensive herbage removal intensity in a spatio-temporally complex grassland management can create a reduced height of the vegetation, resulting in a sunnier and drier microclimate (benefits light-preferring and drought tolerant species) (Wan et al. 2002). Periods with less intensive management (e.g., one mowing per year) favours species that prefer a milder microclimate, are taller and grow faster (Steen 1980). Thus, higher spatio-temporal complexity of grassland management (e.g., leaving unmown refuge strips with location varying from year to year; or grazing with changing regimes and starting time year by year) coupled with lower herbage removal intensity provides a great opportunity for more plant species with various competitive strategies to coexist (see Tables 3 and 4, Appendix Tables 7, 8, Fig. 1) (Austrheim and Eriksson 2001; Duru et al. 2005). Based on other studies, these abovementioned, positive effects also can be helped by the plant structure providing effect of extensive grazing (Kelemen et al. 2017). In summary, herbage removal intensity and spatio-temporal complexity had stronger effects on grassland diversity and on PFT groups than management type (Figs. 1, 2), furthermore their importance is greater in effective conservation practice and planning than management types only. 


\section{Complex effects and hierarchy of different management factors in conservation}

Studied management factors and their parameters (different levels of intensity and spatiotemporal complexity) can be combined in several ways (theoretically $3^{3}=27$ ways). At the studied sites 7 combinations were realized (for more detailed information, see Table 1, Appendix Fig. 3, Appendix Table 12). The combination of low herbage removal intensity and high spatio-temporal complexity resulted in the highest number of species by far, positively affecting the cover of forbs and number of specialist species. This combination has the greatest relevance in conservation management practice. Furthermore, based on model selection, a definite hierarchy can be established among the three management factors based on their overall conservation relevance: (1) spatio-temporal complexity of management had the strongest explanatory power on most of the response variables (especially on plant diversity, generalist species cover and species number of forbs and specialists); (2) herbage removal intensity had less, but similarly great importance in conservation, and (3) management type was the third factor in the hierarchical order of the management factors' importance (Table 3). Based on this relevance, grassland conservation planning should take different levels of spatio-temporal complexity of grassland management into consideration to develop more comprehensive management systems. We recommend to investigate the effects of spatio-temporal complexity, herbage removal intensity of management and different management types in different grassland habitats to develop more effective nature conservation grassland management. Considering the significance of the relevance of management factors, a more comprehensive and detailed conservation planning and management would be achieved and oversimplifying models and approaches would be avoided in conservation studies and practice.

\section{Conclusions}

In our study we showed that spatio-temporal complexity, herbage removal intensity and management type have a significant role in affecting species composition and diversity of managed grasslands. Thus, conservation management considering only one or two management factors (e.g. only effects of mowing and/or management intensity in a specific region) can be recognised only with limitations regarding conservation planning and management. Complexity levels of applied management factors in space and time together with other technical details (several types and levels of management intensity and management complexity) are highly important in nature conservation management, however, these aspects are definitely understudied. Determining the applicable management factors, and their adequate combinations in accordance with local circumstances on a system level is an urgent need in nature conservation. Thus, resource managers should be very careful in management planning to avoid the potentially false application of oversimplified models and knowledge acquired by them in other regions. The results of this study hopefully shed light on the importance more complex, system-level models in effective conservation management planning of High Nature Value grasslands.

\section{Appendix}

See Tables 6, 7, 8, 9, 10, 11 and 12, Fig. 3. 
Table 6 Effects of different management types on grassland diversity and coverages of different functional types

\begin{tabular}{lccc}
\hline Dependent variables & Mown & Combined & Grazed \\
\hline Species number & $26.32 \pm 4.177 \mathrm{a}$ & $26.220 \pm 4.542 \mathrm{a}$ & $23.790 \pm 5.171 \mathrm{a}$ \\
Shannon diversity & $2.221 \pm 0.295 \mathrm{a}$ & $2.275 \pm 0.246 \mathrm{a}$ & $2.058 \pm 0.355 \mathrm{a}$ \\
Simpson diversity & $0.826 \pm 0.062 \mathrm{a}$ & $0.828 \pm 0.057 \mathrm{a}$ & $0.778 \pm 0.096 \mathrm{a}$ \\
Forb species cover $(\%)$ & $33.874 \pm 15.255 \mathrm{a}$ & $31.501 \pm 17.454 \mathrm{a}$ & $27.019 \pm 13.338 \mathrm{a}$ \\
Grass species cover $(\%)$ & $47.548 \pm 14.514 \mathrm{a}$ & $53.169 \pm 21.616 \mathrm{a}$ & $59.385 \pm 19.643 \mathrm{a}$ \\
Disturbance-tolerant species cover $(\%)$ & $31.852 \pm 17.027 \mathrm{a}$ & $18.688 \pm 8.163 \mathrm{a}$ & $20.607 \pm 13.384 \mathrm{a}$ \\
Generalist species cover $(\%)$ & $19.036 \pm 10.232 \mathrm{a}$ & $27.478 \pm 17.998 \mathrm{a}$ & $18.547 \pm 13.365 \mathrm{a}$ \\
Natural competitor species cover $(\%)$ & $40.485 \pm 15.948 \mathrm{a}$ & $39.104 \pm 18.590 \mathrm{a}$ & $49.049 \pm 21.534 \mathrm{a}$ \\
Ruderal competitor species cover $(\%)$ & $2.771 \pm 5.183 \mathrm{a}$ & $5.685 \pm 11.988 \mathrm{a}$ & $4.945 \pm 9.829 \mathrm{a}$ \\
Specialist species cover $(\%)$ & $0.282 \pm 0.921 \mathrm{a}$ & $0.501 \pm 1.173 \mathrm{a}$ & $0.778 \pm 1.928 \mathrm{a}$ \\
Protected species cover $(\%)$ & $2.592 \pm 4.246 \mathrm{a}$ & $0.282 \pm 0.830 \mathrm{a}$ & $0.853 \pm 1.870 \mathrm{a}$ \\
\hline
\end{tabular}

Significant differences among different type of management in every cases are signed with different letters ('a', 'b' and 'c') next to each management type averages and standard deviations (MEAN \pm SD in the table, under every column of management types, namely mown, combined and grazed). If there is not any difference between management types, letters aren't different from each other. Probability level of LMER and GLMER Tukey post hoc tests was $\mathrm{p}<0.05$

Table 7 Effects of different levels of herbage removal intensity on grassland diversity and coverages of different functional types

\begin{tabular}{lccc}
\hline Dependent variables & Low & Medium & High \\
\hline Species number & $27.549 \pm 4.473 \mathrm{a}$ & $24.968 \pm 2.787 \mathrm{a}$ & $20.74 \pm 3.361 \mathrm{~b}$ \\
Shannon diversity & $2.236 \pm 0.298 \mathrm{a}$ & $2.214 \pm 0.297 \mathrm{a}$ & $1.979 \pm 0.334 \mathrm{a}$ \\
Simpson diversity & $0.819 \pm 0.069 \mathrm{a}$ & $0.814 \pm 0.08 \mathrm{a}$ & $0.770 \pm 0.097 \mathrm{a}$ \\
Forb species cover $(\%)$ & $34.514 \pm 15.386 \mathrm{a}$ & $27.703 \pm 14.281 \mathrm{ab}$ & $23.484 \pm 12.632 \mathrm{~b}$ \\
Grass species cover $(\%)$ & $45.663 \pm 17.583 \mathrm{a}$ & $60.750 \pm 16.338 \mathrm{~b}$ & $66.579 \pm 16.198 \mathrm{~b}$ \\
Disturbance-tolerant species cover $(\%)$ & $26.127 \pm 15.917 \mathrm{a}$ & $19.472 \pm 10.822 \mathrm{a}$ & $20.937 \pm 13.207 \mathrm{a}$ \\
Generalist species cover $(\%)$ & $23.348 \pm 13.82 \mathrm{a}$ & $24.447 \pm 15.504 \mathrm{a}$ & $13.962 \pm 11.98 \mathrm{a}$ \\
Natural competitor species cover $(\%)$ & $39.056 \pm 17.472 \mathrm{a}$ & $48.359 \pm 16.548 \mathrm{a}$ & $50.945 \pm 23.094 \mathrm{a}$ \\
Ruderal competitor species cover $(\%)$ & $2.253 \pm 6.639 \mathrm{a}$ & $3.967 \pm 7.222 \mathrm{ab}$ & $8.881 \pm 12.823 \mathrm{~b}$ \\
Specialist species cover $(\%)$ & $0.672 \pm 1.265 \mathrm{a}$ & $1.049 \pm 2.758 \mathrm{a}$ & $0.08 \pm 0.444 \mathrm{a}$ \\
Protected species cover $(\%)$ & $1.996 \pm 3.573 \mathrm{a}$ & $0.115 \pm 0.281 \mathrm{a}$ & $0.501 \pm 1.125 \mathrm{a}$ \\
\hline
\end{tabular}

Significant differences among different herbage removal intensity levels are signed with different letters ('a', ' $b$ ' and 'c') next to each herbage removal intensity level averages and standard deviations (MEAN \pm SD in the table, under every column of levels, namely low, medium and high). If there is not any difference between levels, letters aren't different from each other. Probability level of LMER and GLMER Tukey post hoc tests was $\mathrm{p}<0.05$ 
Table 8 Effects of different levels of spatio-temporal complexity of management on grassland diversity and coverages of different functional types

\begin{tabular}{lccc}
\hline Dependent variables & Low & Medium & High \\
\hline Species number & $19.267 \pm 2.803 \mathrm{a}$ & $25.604 \pm 3.883 \mathrm{~b}$ & $28.968 \pm 4.778 \mathrm{c}$ \\
Shannon diversity & $1.821 \pm 0.284 \mathrm{a}$ & $2.217 \pm 0.275 \mathrm{~b}$ & $2.271 \pm 0.342 \mathrm{~b}$ \\
Simpson diversity & $0.730 \pm 0.097 \mathrm{a}$ & $0.820 \pm 0.066 \mathrm{~b}$ & $0.817 \pm 0.085 \mathrm{ab}$ \\
Forb species cover (\%) & $23.203 \pm 13.429 \mathrm{a}$ & $31.857 \pm 16.353 \mathrm{a}$ & $30.374 \pm 9.943 \mathrm{a}$ \\
Grass species cover (\%) & $69.243 \pm 16.415 \mathrm{a}$ & $52.274 \pm 18.299 \mathrm{~b}$ & $47.994 \pm 19.383 \mathrm{~b}$ \\
Disturbance-tolerant species cover (\%) & $22.335 \pm 15.728 \mathrm{a}$ & $24.467 \pm 14.969 \mathrm{a}$ & $20.716 \pm 11.708 \mathrm{a}$ \\
Generalist species cover (\%) & $9.521 \pm 4.969 \mathrm{a}$ & $23.220 \pm 15.426 \mathrm{~b}$ & $23.148 \pm 10.399 \mathrm{~b}$ \\
Natural competitor species cover (\%) & $55.740 \pm 25.553 \mathrm{a}$ & $41.982 \pm 17.364 \mathrm{a}$ & $40.910 \pm 18.317 \mathrm{a}$ \\
Ruderal competitor species cover (\%) & $9.002 \pm 13.410 \mathrm{a}$ & $3.924 \pm 7.627 \mathrm{a}$ & $2.145 \pm 9.284 \mathrm{a}$ \\
Specialist species cover $(\%)$ & $0.133 \pm 0.571 \mathrm{a}$ & $0.533 \pm 1.684 \mathrm{a}$ & $1.115 \pm 1.475 \mathrm{a}$ \\
Protected species cover $(\%)$ & $0.785 \pm 1.375 \mathrm{a}$ & $1.267 \pm 3.120 \mathrm{a}$ & $1.485 \pm 2.572 \mathrm{a}$ \\
\hline
\end{tabular}

Significant differences among different spatio-temporal complexity levels are signed with different letters ('a', 'b' and 'c') next to each spatio-temporal complexity level averages and standard deviations $(\mathrm{MEAN} \pm \mathrm{SD}$ in the table, under every column of levels, namely low, medium and high). If there is not any difference between levels, letters aren't different from each other. Probability level of LMER and GLMER Tukey post hoc tests was $\mathrm{p}<0.05$

Table 9 Effects of management types on species numbers of different plant functional type groups

\begin{tabular}{lrrr}
\hline Dependent variables & \multicolumn{1}{c}{ Mown } & \multicolumn{1}{c}{ Combined } & \multicolumn{1}{c}{ Grazed } \\
\hline Forb species number & $14.900 \pm 3.477 \mathrm{a}$ & $14.463 \pm 4.130 \mathrm{a}$ & $13.284 \pm 3.887 \mathrm{a}$ \\
Grass species number & $7.420 \pm 1.592 \mathrm{a}$ & $7.780 \pm 1.681 \mathrm{a}$ & $7.420 \pm 1.672 \mathrm{a}$ \\
Disturbance-tolerant species number & $9.780 \pm 2.477 \mathrm{a}$ & $9.683 \pm 2.115 \mathrm{a}$ & $8.704 \pm 2.487 \mathrm{a}$ \\
Generalist species number & $10.060 \pm 2.551 \mathrm{a}$ & $10.000 \pm 2.729 \mathrm{a}$ & $8.346 \pm 3.298 \mathrm{a}$ \\
Natural competitor species number & $4.640 \pm 1.274 \mathrm{a}$ & $4.561 \pm 1.550 \mathrm{a}$ & $4.580 \pm 1.322 \mathrm{a}$ \\
Ruderal competitor species number & $0.880 \pm 0.746 \mathrm{a}$ & $1.122 \pm 0.980 \mathrm{a}$ & $1.000 \pm 0.837 \mathrm{a}$ \\
Specialist species number & $0.400 \pm 0.495 \mathrm{a}$ & $0.463 \pm 0.840 \mathrm{a}$ & $0.593 \pm 0.877 \mathrm{a}$ \\
Protected species number & $0.660 \pm 0.688 \mathrm{a}$ & $0.390 \pm 0.666 \mathrm{a}$ & $0.555 \pm 0.707 \mathrm{a}$ \\
\hline
\end{tabular}

Significant differences among different types of management are signed with different letters ('a', 'b' and ' $c$ ') next to each management type averages and standard deviations (MEAN \pm SD in the table, under every column of management types, namely mown, combined and grazed). If there is not any difference between management types, letters aren't different from each other. Probability level of LMER and GLMER Tukey post hoc tests was $p<0.05$ 
Table 10 Effects of herbage removal intensity on species number of different plant functional types

\begin{tabular}{lrrr}
\hline Dependent variables & \multicolumn{1}{l}{ Low } & \multicolumn{1}{l}{ Medium } & \multicolumn{1}{l}{ High } \\
\hline Forb species number & $15.934 \pm 3.777 \mathrm{a}$ & $13.742 \pm 2.081 \mathrm{a}$ & $10.760 \pm 2.446 \mathrm{~b}$ \\
Grass species number & $7.495 \pm 1.779 \mathrm{a}$ & $8.161 \pm 1.485 \mathrm{a}$ & $7.120 \pm 1.380 \mathrm{a}$ \\
Disturbance-tolerant species number & $10.066 \pm 2.666 \mathrm{a}$ & $8.935 \pm 1.340 \mathrm{ab}$ & $7.960 \pm 1.916 \mathrm{~b}$ \\
Generalist species number & $10.703 \pm 2.601 \mathrm{a}$ & $9.290 \pm 2.383 \mathrm{a}$ & $6.540 \pm 2.349 \mathrm{~b}$ \\
Natural competitor species number & $4.725 \pm 1.430 \mathrm{a}$ & $4.839 \pm 1.293 \mathrm{a}$ & $4.200 \pm 1.195 \mathrm{a}$ \\
Ruderal competitor species number & $0.780 \pm 0.814 \mathrm{a}$ & $1.032 \pm 0.752 \mathrm{a}$ & $1.360 \pm 0.851 \mathrm{a}$ \\
Specialist species number & $0.758 \pm 0.835 \mathrm{a}$ & $0.419 \pm 0.848 \mathrm{a}$ & $0.100 \pm 0.303 \mathrm{a}$ \\
Protected species number & $0.692 \pm 0.756 \mathrm{a}$ & $0.323 \pm 0.541 \mathrm{a}$ & $0.420 \pm 0.609 \mathrm{a}$ \\
\hline
\end{tabular}

Significant differences among different herbage removal intensity levels are signed with different letters ('a', ' $b$ ' and 'c') next to each herbage removal intensity level averages and standard deviations (MEAN \pm SD in the table, under every column of levels, namely low, medium and high). If there is not any difference between levels, letters aren't different from each other. Probability level of LMER and GLMER Tukey post hoc tests was $\mathrm{p}<0.05$

Table 11 Effects of spatio-temporal complexity of management on species number of different plant functional types

\begin{tabular}{lrrr}
\hline Dependent variables & \multicolumn{1}{l}{ Low } & \multicolumn{1}{l}{ Medium } & \multicolumn{1}{l}{ High } \\
\hline Forb species number & $10.333 \pm 2.426 \mathrm{a}$ & $14.234 \pm 3.368 \mathrm{~b}$ & $16.903 \pm 4.020 \mathrm{~b}$ \\
Grass species number & $6.700 \pm 1.291 \mathrm{a}$ & $7.622 \pm 1.526 \mathrm{a}$ & $7.871 \pm 2.125 \mathrm{a}$ \\
Disturbance-tolerant species number & $7.500 \pm 1.757 \mathrm{a}$ & $9.396 \pm 2.103 \mathrm{~b}$ & $10.419 \pm 3.202 \mathrm{~b}$ \\
Generalist species number & $5.400 \pm 1.958 \mathrm{a}$ & $9.748 \pm 2.567 \mathrm{~b}$ & $11.129 \pm 2.526 \mathrm{~b}$ \\
Natural competitor species number & $4.367 \pm 1.129 \mathrm{a}$ & $4.631 \pm 1.307 \mathrm{a}$ & $4.677 \pm 1.720 \mathrm{a}$ \\
Ruderal competitor species number & $1.267 \pm 0.907 \mathrm{a}$ & $0.955 \pm 0.802 \mathrm{a}$ & $0.871 \pm 0.922 \mathrm{a}$ \\
Specialist species number & $0.167 \pm 0.379 \mathrm{a}$ & $0.378 \pm 0.633 \mathrm{a}$ & $1.290 \pm 1.006 \mathrm{~b}$ \\
Protected species number & $0.600 \pm 0.675 \mathrm{a}$ & $0.459 \pm 0.629 \mathrm{a}$ & $0.806 \pm 0.873 \mathrm{a}$ \\
\hline
\end{tabular}

Significant differences among different spatio-temporal complexity levels are signed with different letters ('a', 'b' and 'c') next to each spatio-temporal complexity level averages and standard deviations $(\mathrm{MEAN} \pm \mathrm{SD}$ in the table, under every column of levels, namely low, medium and high). If there is not any difference between levels, letters aren't different from each other. Probability level of LMER and GLMER Tukey post hoc tests was $\mathrm{p}<0.05$ 


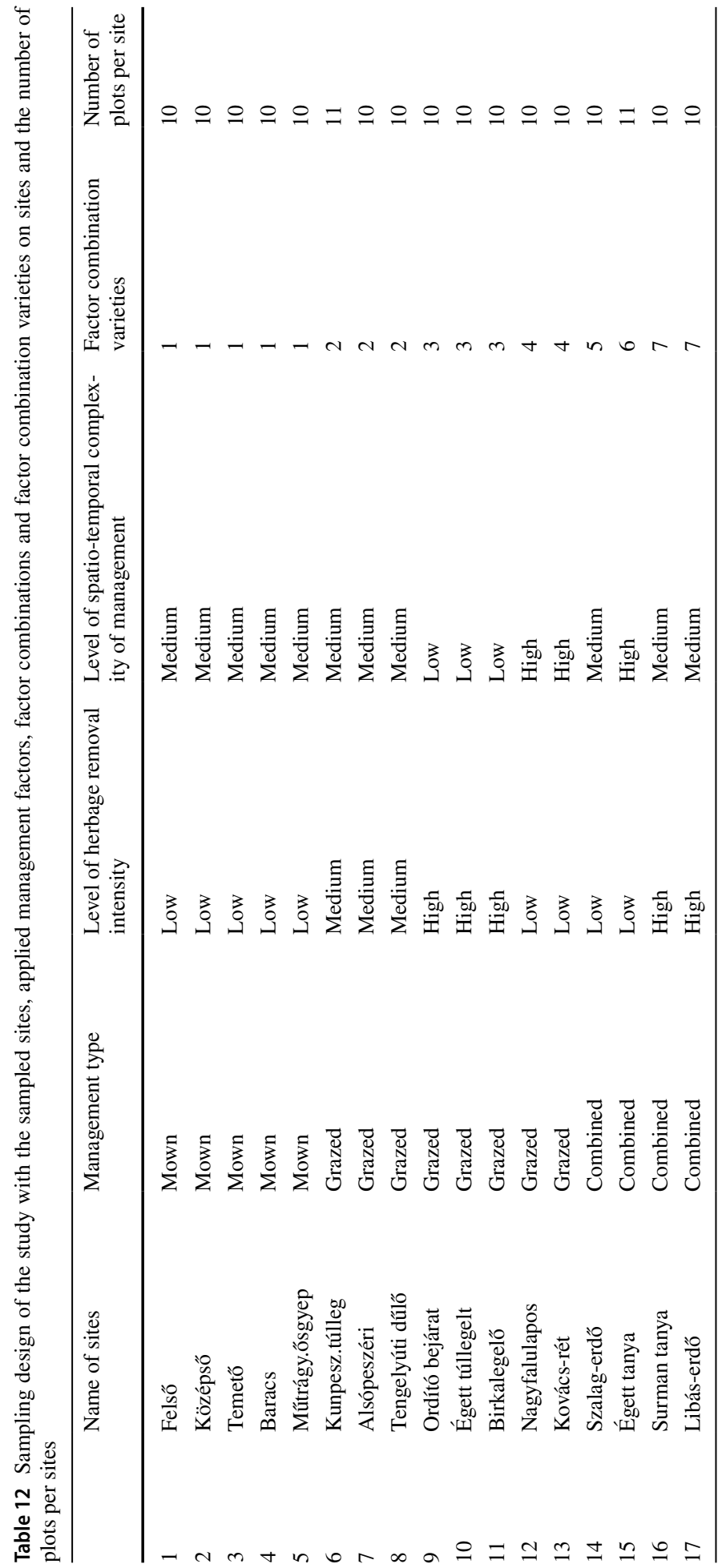




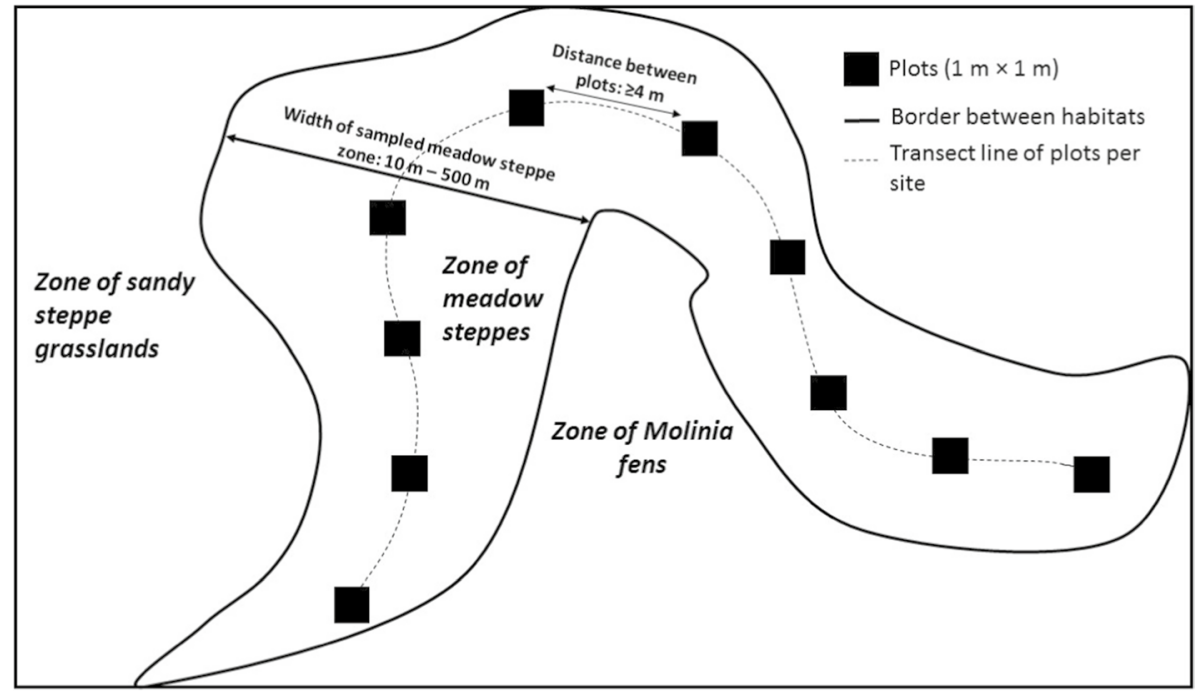

Fig. 3 Sampling protocol of every studied grassland site with the schematic form of transitional meadow steppe zone between Molinia fens and sandy steppe grasslands. Form of transect line with $1 \mathrm{~m} \times 1 \mathrm{~m}$ plots was fitted to the specific forms of each meadow steppe sites

Acknowledgements We hereby thank the Environmental Sciences Doctoral School of the Hungarian University of Agriculture and Life Sciences and the ÚNKP-19-3-I-SZIE-37 scholarship for the support of this study. Dániel Babai was supported by the MTA Premium Postdoctoral Research Fellowship Program of the Hungarian Academy of Sciences [Grant Number: PPD008/2017], and by the MTA Momentum Program [Grant Number: LENDULET_2020-56]. We also thank Patrick Mullowney and Ben Schutz for the English revision.

Funding Open access funding provided by Hungarian University of Agriculture and Life Sciences. Funding was provided by Research Centre of Excellence (Grant No. 8526-5/2014/TUDPOL) and Magyar Tudományos Akadémia (Grant No. PPD008/2017)

Open Access This article is licensed under a Creative Commons Attribution 4.0 International License, which permits use, sharing, adaptation, distribution and reproduction in any medium or format, as long as you give appropriate credit to the original author(s) and the source, provide a link to the Creative Commons licence, and indicate if changes were made. The images or other third party material in this article are included in the article's Creative Commons licence, unless indicated otherwise in a credit line to the material. If material is not included in the article's Creative Commons licence and your intended use is not permitted by statutory regulation or exceeds the permitted use, you will need to obtain permission directly from the copyright holder. To view a copy of this licence, visit http://creativecommons.org/licenses/by/4.0/.

\section{References}

Allen VG, Batello C, Berretta EJ, Hodgson J, Kothmann M, Li X et al (2011) An international terminology for grazing lands and grazing animals. Grass Forage Sci 66:2-29. https://doi.org/10.1111/j.1365-2494. 2010.00780.x

Austrheim G, Eriksson O (2001) Plant species diversity and grazing in the Scandinavian mountainspatterns and processes at different spatial scales. Ecography 24:683-695. https://doi.org/10.1111/j. 1600-0587.2001.tb00530.x

Babai D, Molnár Z (2014) Small-scale traditional management of highly species-rich grasslands in the Carpathians. Agric Ecosyst Environ 182:123-130. https://doi.org/10.1016/j.agee.2013.08.018 
Babai D, Molnár Á, Molnár Z (2014) “Ahogy gondozza, úgy veszi hasznát” Hagyományos ökológiai tudás és gazdálkodás Gyimesben. (Traditional ecological knowledge and land use in Gyimes (Eastern-Carpathians). MTA Bölcsészettudományi Kutatóközpont Néprajztudományi Intézet-MTA Ökológiai Kutatóközpont Ökológiai és Botanikai Intézet, Budapest-Vácrátót. p 174

Babai D, Tóth A, Szentirmai I, Biró M, Máté A, Demeter L, Szépligeti M, Varga A, Molnár Á, Kun R, Molnár Zs (2015) Do conservation and agri-environmental regulations effectively support traditional small-scale farming in East-Central European cultural landscapes? Biodivers Conserv 24:3305-3327. https://doi.org/10.1007/s10531-015-0971-z

Bakker JP, Berendse F (1999) Constraints in the restoration of ecological diversity in grassland and heathland communities. Trens Ecol Evol 14:63-68. https://doi.org/10.1016/S0169-5347(98) 01544-4

Borhidi A (1995) Social behaviour types, the naturalness and relative ecological indicator values of the higher plants in the Hungarian Flora. Acta Bot Hung 39:97-181

Borhidi A (1996) Critical revision of the Hungarian plant communities. Janus Pannonius University, Pécs

Burnham KP, Anderson DR (2002) Model selection and multimodel inference: a practical information theoretic approach, 2nd edn. Springer, New York, p 10. https://doi.org/10.1007/b97636

Burton RJ, Paragahawewa UH (2011) Creating culturally sustainable agri-environmental schemes. J Rural Stud 27:95-104. https://doi.org/10.1016/j.jrurstud.2010.11.001

Catorci A, Cesaretti S, Malatesta L, Tardella FM (2014) Effects of grazing vs mowing on the functional diversity of sub-Mediterranean productive grasslands. Appl Veg Sci 17:658-669. https://doi.org/10. 1111/avsc. 12103

Csergő AM, Demeter L, Turkington R (2013) Declining diversity in abandoned grasslands of the Carpathian mountains: do dominant species matter? PLoS One 8:e73533. https://doi.org/10.1371/journal. pone. 0073533

Dahlström A, Iuga AM, Lennartsson T (2013) Managing biodiversity rich hay meadows in the EU: a comparison of Swedish and Romanian grasslands. Environ Conserv 40:194-205. https://doi.org/10.1017/ S0376892912000458

Diaz S, Cabido M (1997) Plant functional types and ecosystem function in relation to global change. J Veg Sci 8:463-474. https://doi.org/10.2307/3237198

De Bello F, Lepš J, Sebastià M-T (2006) Variations in species and functional plant diversity along climatic and grazing gradients. Ecography 29:801-810. https://doi.org/10.1111/j.2006.0906-7590.04683.x

Dengler J, Janišová M, Török P, Wellstein C (2014) Biodiversity of Palaearctic grasslands: a synthesis. Agric Ecosyst Environ 182:1-14. https://doi.org/10.1016/j.agee.2013.12.015

Duru M, Tallowin J, Cruz P (2005) Functional diversity in low-input grassland farming systems: characterisation, effect and management. Agron Res 3:125-138 (hal-02676364f)

Fedrigo JK, Ataide PF, Filho JA, Oliveira LV, Jaurena M, Laca EA et al (2018) Temporary grazing exclusion promotes rapid recovery of species richness and productivity in a long-term overgrazed Campos grassland. Restor Ecol 26:677-685. https://doi.org/10.1111/rec.12635

Fischer M, Wipf S (2002) Effect of low-intensity grazing on the species-rich vegetation of traditionally mown subalpine meadows. Biol Conserv 104:1-11. https://doi.org/10.1016/S0006-3207(01)00149-5

Galvánek D, Lepš J (2008) Changes of species richness pattern in mountain grasslands: abandonment versus restoration. Biodivers Conserv 17:3241-3253. https://doi.org/10.1007/s10531-008-9424-2

Habel JC, Dengler J, Janišová M, Török P, Wellstein C, Wiezik M (2013) European grassland ecosystems: threatened hotspots of biodiversity. Biodivers Conserv 22:2131-2138. https://doi.org/10. 1007/s10531-013-0537-x

Hargitai Z (1940) Nagykőrös növényvilága. II. A homoki növényszövetkezetek. Bot Közlem 37:205-240

Házi J, Bartha S, Szentes S, Wichmann B, Penksza K (2011) Seminatural grassland management by mowing of Calamagrostis epigejos in Hungary. Plant Biosyst 145:699-707. https://doi.org/10. 1080/11263504.2011.601339

Hobohm C, Bruchmann I (2009) Endemische Gefäßpflanzen und ihre Habitate in Europa-Plädoyer für den Schutz der Grasland-Ökosysteme. Ber Reinhold-Tüxen-Ges 21:142-161

Imrichova Z, Vrahnakis MS (2005) Revealing changes in biodiversity pattern by means of PTFs. In Lillak R, Viiralt R, Linke A, Geherman V (eds) Integrating efficient grassland farming and biodiversity. Greif Print House, Tartu, pp 128-132

Karátson D (2002) A Keleti-Kárpátok. In: Karátson D (ed) Magyarország földje. Magyar Könyvklub, Budapest, pp 417-425

Kelemen A, Tölgyesi Cs, Kun R, Molnár Zs, Vadász Cs, Tóth K (2017) Positive small-scale effects of shrubs on diversity and flowering in pastures. Tuexen 37:399-413. https://doi.org/10.14471/2017. 37.009 
Kun A, Ruprecht E, Bartha S, Szabó A, Virágh K (2007) Az Erdélyi Mezőség kincse: a gyepvegetáció egyedülálló gazdagsága. Kitaibel 12:88-96

Kun R, Bartha S, Malatinszky Á, Molnár Z, Lengyel A, Babai D (2019) "Everyone does it a bit differently!": Evidence for a positive relationship between micro-scale land-use diversity and plant diversity in hay meadows. Agric Ecosyst Environ 283:106-556. https://doi.org/10.1016/j.agee.2019.05. 015

MacDonald D, Crabtree JR, Wiesinger G, Dax T, Stamou N, Fleury P, Lazpita JG (2000) Agricultural abandonment in mountain areas of Europe: environmental consequences and policy response. J Environ Manag 59:47-69. https://doi.org/10.1006/jema.1999.0335

Malatinszky Á (2016) Stakeholder perceptions of climate extremes' effects on management of protected grasslands in a Central European area. Weather Clim Soc 8:209-217. https://doi.org/10.1175/ WCAS-D-15-0029.1

Marini L, Scotton M, Klimek S, Isselstein J, Pecile A (2007) Effects of local factors on plant species richness and composition of Alpine meadows. Agric Ecosyst Environ 119:281-288. https://doi.org/ 10.1016/j.agee.2006.07.015

Öckinger E, Smith HG (2006) Landscape composition and habitat area affects butterfly species richness in semi-natural grasslands. Oecologia 149:526-534. https://doi.org/10.1007/s00442-006-0464-6

Öckinger E, Eriksson AK, Smith HG (2006) Effects of grassland abandonment, restoration and management on butterflies and vascular plants. Biol Conserv 133:291-300. https://doi.org/10.1016/j. biocon.2006.06.009

Plieninger T, Höchtl F, Spek T (2006) Traditional land-use and nature conservation in European rural landscapes. Environ Sci Policy 9:317-321. https://doi.org/10.1016/j.envsci.2006.03.001

Posada D, Buckley TR (2004) Model selection and model averaging in phylogenetics: advantages of Akaike information criterion and Bayesian approaches over likelihood ratio tests. Syst Biol 53:793808. https://doi.org/10.1080/10635150490522304

Poschlod P, Bakker JP, Kahmen S (2005) Changing land use and its impact on biodiversity. Basic Appl Ecol 6:93-98. https://doi.org/10.1016/j.baae.2004.12.001

R Core Team (2018) R: a language and environment for statistical computing. R Foundation for Statistical Computing, Vienna. https://www.R-project.org

Ruprecht E, Enyedi MZ, Eckstein RL, Donath TW (2010) Restorative removal of plant litter and vegetation 40 years after abandonment enhances re-emergence of steppe grassland vegetation. Biol Conserv 143:449-456. https://doi.org/10.1016/j.biocon.2009.11.012

Schmitz A, Isselstein J (2020) Effect of grazing system on grassland plant species richness and vegetation characteristics: comparing horse and cattle grazing. Sustainability 12:3300. https://doi.org/10. 3390/su12083300

Steen E (1980) Dynamics and production of semi-natural grassland vegetation in Fennoscandia in relation to grazing management. Acta Phytogeogr Suec 68:153-156

Söderström B, Svensson B, Vessby K, Glimskär A (2001) Plants, insects and birds in semi-natural pastures in relation to local habitat and landscape factors. Biodivers Conserv 10:1839-1863. https:// doi.org/10.1023/A:1013153427422

Spiegelberger T, Deléglise C, DeDanieli S, Bernard-Brunet C (2010) Resilience of acid subalpine grassland to short-term liming and fertilisation. Agric Ecosyst Environ 137:158-162. https://doi.org/10. 1016/j.agee.2010.01.017

Szentes S, Sutyinszki Z, Szabó G, Zimmermann Z, Házi J, Wichmann B et al (2012) Grazed Pannonian grassland beta-diversity changes due to C 4 yellow bluestem. Cent Eur J Biol 7:1055-1065. https://doi. org/10.2478/s11535-012-0101-9

Szépligeti M, Kőrösi Á, Szentirmai I, Házi J, Bartha D, Bartha S (2018) Evaluating alternative mowing regimes for conservation management of Central European mesic hay meadows: a field experiment. Plant Biosyst 152:90-97. https://doi.org/10.1080/11263504.2016.1255268

Tälle M, Deák B, Poschlod P, Valkó O, Westerberg L, Milberg P (2016) Grazing vs. mowing: a meta-analysis of biodiversity benefits for grassland management. Agric Ecosyst Environ 222:200-212. https://doi. org/10.1016/j.agee.2016.02.008

Tölgyesi Cs, Zalatnai M, Erdős L, Bátori Z, Hupp NR, Körmöczi L (2016) Unexpected ecotone dynamics of a sand dune vegetation complex following water table decline. J Plant Ecol 9:40-50. https://doi.org/ 10.1093/jpe/rtv032

Vadász Cs, Máté A, Kun R, Vadász-Besnyői V (2016) Quantifying the diversifying potential of conservation management systems: an evidence-based conceptual model for managing species-rich grasslands. Agric Ecosyst Environ 234:134-141. https://doi.org/10.1016/j.agee.2016.03.044

Wan S, Luo Y, Wallace L (2002) Changes in microclimate induced by experimental warming and clipping in tallgrass prairie. Glob Chang Biol 8:754-768. https://doi.org/10.1046/j.1365-2486.2002.00510.x 
Wilson JB, Peet RK, Dengler J, Pärtel M (2012) Plant species richness: the world records. J Veg Sci 23:796802. https://doi.org/10.1111/j.1654-1103.2012.01400.x

\section{Web references}

http\#1:http://www.termeszetvedelem.hu/index.php?lang=en

Publisher's Note Springer Nature remains neutral with regard to jurisdictional claims in published maps and institutional affiliations.

\section{Authors and Affiliations}

\section{Róbert Kun ${ }^{1}$ (D) Dániel Babai ${ }^{2}$. András István Csathó ${ }^{3} \cdot$ Csaba Vadász $^{4}$. Nikoletta Kálmán ${ }^{5} \cdot$ András Máté $^{6}$ Ákos Malatinszky ${ }^{1}$}

1 Department of Nature Conservation and Landscape Management, Hungarian University of Agriculture and Life Sciences, Páter Károly u. 1, Gödöllő 2100, Hungary

2 Research Centre for the Humanities, Institute of Ethnology, Tóth Kálmán u. 4, Budapest 1097, Hungary

3 Körös-Maros National Park Directorate, Anna-liget 1, Szarvas 5540, Hungary

4 Kiskunság National Park Directorate, Liszt Ferenc u. 19, Kecskemet 6000, Hungary

5 Department of Zoology and Ecology, Hungarian University of Agriculture and Life Sciences, Páter Károly u. 1, Gödöllő 2100, Hungary

6 Dorcadion Kft., Kecskemet 6000, Hungary 